\title{
Belediye Üst Kademe Yöneticilerinin Liderlik ve Mesleki Bilgi Kapasitelerinin Geliştirilmesine Yönelik Bir Araştır- ma ve Eğitim Programı Önerisi
}

Onur Kemal Yılmaz ${ }^{1}$

Belediye Üst Kademe Yöneticilerinin Liderlik ve Mesleki Bilgi Kapasitelerinin Geliştirilmesine Yönelik Bir Araştırma ve Eğitim Programı Önerisi

\section{Öz}

Belediyeler yerel nitelikli ve kent ölçekli hizmetlerin üretilmesinde en yetkili kamu idareleridirler. Dolayısıyla belediye üst kademe yöneticilerinin sahip oldukları liderlik yetenekleri ve mesleki bilgi birikimleri, kentlerin ve belediyelerin etkin yönetilmesinde dikkate alınması gereken unsurlar olarak değerlendirilebilirler. Bu konuyla ilgili olarak çalışma kapsamında liderlik ve mesleki eğitim kavramlarına dair temel bilgiler açıklanmış ve Edremit Belediyesi'nde görevli üst kademe yöneticilerin görüşlerine başvurulan bir anket çalışması gerçekleştirilmiştir. İlgili anket uyarınca liderlik ve mesleki bilgi konularının belediye üst kademe yöneticileri tarafından önemsendikleri ve bu yönde eğitimlerin kendilerine verilmesine istekli oldukları sonucuna varılmıştır. Saha araştırmasına istinaden çalışmanın son bölümünde, belediye üst kademe yöneticilerine yönelik liderlik ve mesleki bilgi kapasitelerini geliştirici bir eğitim program önerisi hazırlanmıştır. Önerilen eğitim programı üç aylık bir zaman dilimini kapsayacak şekilde üç ayrı bölümden oluşmaktadır.

Anahtar Kelimeler: Liderlik, Mesleki Eğitim, Stratejik Liderlik, Karizmatik Liderlik, Hizmetkâr Liderlik

\begin{abstract}
A Research and Training Program Proposal for the Development of Leadership and Occupational Knowledge Capabilities of Municipal High Level Managers
\end{abstract}

Abstract

Municipalities are the most authoritative public administrations in the production of local and urban services. Therefore, the leadership skills and professional knowledge of the senior executives of the municipalities can be considered as factors that should be taken into consideration in the effective management of cities and municipalities. Within the scope of this study, basic information about the concepts of leadership and vocational education was explained and a survey was conducted with the managers of Edremit municipality. According to the survey, it has been concluded that the leadership and professional knowledge subjects are cared by the senior managers of the municipality and they are eager to get trainings in these subjects. In the last part of the study, a training program proposal was developed to improve the leadership and professional knowledge capacities of the senior managers of the municipalities. The proposed training program consists of three separate sections covering a three-month period.

Keywords: Leadership, Vocational Education, Strategic Leadership, Charismatic Leadership, Servant Leadership

\section{Giriş}

Belediyeler kentlerin fiziksel, ekonomik ve sosyal sorunlarını çözmede; ayrıca onların geleceğini inşa etmede en öne çıkan kamu kurumlarıdırlar. Belediyelerin hizmet kapasitelerini belirleyen en önemli unsur ise belediye üst kademe yöneticilerin sahip oldukları niteliklerdir. Bu kapsamda belediyede görevli başkan, başkan yardımcısı, genel sekreter, genel sekreter yardımcısı, daire başkanı ve müdürden oluşan üst kademe yöneticilerin sahip oldukları niteliklerin geliştirilmesi, onların kente yönelik daha kaliteli hizmet üretmelerini sağlayabilecektir. Bu çalışma kapsamında belediye üst kademe yöneticilerinin daha etkin hizmet üretebilmeleri için belirlenmiş olan nitelikler; liderlik ve mesleki bilgi kapasiteleridir. Liderlik yeteneği, belediye üst kademe yöneticilerinin astlarını daha etkin organize etmede ve yönetmede ihtiyaç duy-

\footnotetext{
${ }^{1}$ Dr. Öğr. Üyesi, Bandırma Onyedi Eylül Üniversitesi, Erdek Meslek Yüksekokulu, Yerel Yönetimler Programı, yilmazonurkemal@gmail.com, Yazar ORCID bilgisi: https://orcid.org/0000-0003-2371-683X.
} 
dukları bir bileşenken; mesleki bilgi seviyesi ise belediye üst kademe yöneticilerinin görevlerini daha etkin şekilde yapmalarını sağlayacak olan bileşendir. Bu bakış açısından hareketle belediye üst kademe yöneticilerinin sahip oldukları liderlik ve mesleki bilgi kapasitelerinin arttırılmaSı, üzerinde çalışılması gereken bir alan olarak görülebilir. Bunun için de belediye üst kademe yöneticilerine yönelik bir eğitim programının hazırlanması konuyla ilgili somut bir adım olarak değerlendirilebilir. Fakat böyle bir eğitim programına ihtiyaç duyulup duyulmadığı da ayrı bir araştırma alanını oluşturmaktadır. Bu kapsamda çalışma içerisinde bir araştırma evreni ve örneklem oluşturulmuştur. Böylece belediye üst kademe yöneticilerinin liderlik ve mesleki bilgi konusunda bir eğitim programına ihtiyaç duyup duymadıkları sorgulanmıştır. Anket yöntemi kullanılarak gerçekleştirilen araştırma kapsamında yanıt aranan sorular şu şekildedir;

- Belediye üst kademe yöneticileri liderlik alanında eksiklikleri olduğunu düşünmekte midirler?

- Belediye üst kademe yöneticileri mesleki bilgi alanında eksiklikleri olduğunu düşünmekte midirler?

- Belediye üst kademe yöneticileri liderlik alanında bir eğitim almayı istemekte midirler?

- Belediye üst kademe yöneticileri mesleki bilgi alanında bir eğitim almayı istemekte midirler?

\section{Türkiye'de Belediyelerin Konumları ve Görevleri}

Türk kamu bürokrasisi, merkezi ve yerinden yönetim olmak üzere ikili bir yapılanmaya sahiptir. Yerinden yönetim yapısı mahalli idareler üzerinden örgütlendirilmiştir. Türkiye'de mahalli idareleri belediyeler, köy yönetimleri ve il özel idareleri oluşturmaktadır. Bu yerel yönetimler içerisinde sahip olunan yetki, bütçe ve kadro ile en öne çıkanı belediyelerdir. İl ve ilçe şeklinde mülki sınırlara ayrılmış olan Türkiye coğrafyasında, belediyeler en geniş ölçekte mahalli müşterek nitelikli hizmetleri yerine getirmektedirler (Türkiye Cumhuriyeti Anayasası, 1982: Md. 123, 126, 127; Belediye Kanunu, 2005). Bu kapsamda Türkiye'de belediyelerin sayıları ve türleri Tablo 1'de gösterilmektedir.

Tablo 1: Türkiye'de Belediyelerin Türleri ve Sayıları

\begin{tabular}{cc} 
Büyükşehir Belediye Sayısı & 30 \\
III Belediye Sayısı & 51 \\
Büyükşehir İlçe Belediyesi Sayısı & 519 \\
İlçe Belediyesi Sayısı & 402 \\
Belde Belediyesi Sayısı & 396 \\
Toplam Belediye Sayısı & $\mathbf{1 3 9 8}$ \\
\hline
\end{tabular}

Kaynak: (E-i̇çişleri, 2018)

Türk kamu bürokrasisi içerisinde belediyeler, mahalli müşterek nitelikli olmak şartıyla oldukça geniş bir sorumluluk üzerinden çalışmalarını yürütmektedirler. Merkezi yönetimin yerel sorunlarla uğraşmasına gerek kalmayacak bir seviyede fiziksel, sosyal, kültürel, sağlık, spor, eğitim ve ekonomiyi kapsayacak şekilde; birçok alanda doğrudan ve dolaylı olarak hizmet üretmektedirler. Belediyelerin yerine getirmeleri gereken görevler ilgili Kanun uyarınca Tablo 2 'deki gibi derlenmiştir. 
Tablo 2: Belediyelerin Temel Görevleri

\begin{tabular}{|c|c|c|}
\hline $\begin{array}{l}\text { İmar, su, kanalizasyon ve ulaşım altyapı } \\
\text { sistemlerini kurmak. }\end{array}$ & $\begin{array}{l}\text { Coğrafi ve kent bilgi sistemleri } \\
\text { kurmak. }\end{array}$ & $\begin{array}{l}\text { Temizlik işleri yapmak ve katı } \\
\text { atık toplamak. }\end{array}$ \\
\hline $\begin{array}{l}\text { Zabıta, itfaiye, kurtarma ve } \\
\text { ambulans işleri yapmak. }\end{array}$ & $\begin{array}{l}\text { Şehir içi trafik düzenlemeleri } \\
\text { yapmak. }\end{array}$ & $\begin{array}{l}\text { Defin ve mezarlık işleri yap- } \\
\text { mak. }\end{array}$ \\
\hline $\begin{array}{l}\text { Ağaçlandırma, park ve yeşil alan yap- } \\
\text { mak. }\end{array}$ & Konut yapmak. & $\begin{array}{c}\text { Kültür, sanat, turizm ve } \\
\text { gençlik hizmetleri yapmak. }\end{array}$ \\
\hline Öğrenci yurtları yapmak. & Sosyal yardım hizmetleri yapmak. & Nikâh işlemleri yapmak. \\
\hline Meslek kazandırma eğitimleri yapmak. & Ekonomiyi ve ticareti geliştirmek. & Okul yapım ve bakım. \\
\hline Hastane yapım ve bakım. & Mabet yapım ve bakım. & Tarihi mekân bakım ve onarımı. \\
\hline Amatör kulüplere yardım yapmak. & Yaşlı ve engellilere yardım yapmak. & Gıda bankacılığı yapmak. \\
\hline
\end{tabular}

Kaynak: (5393 Sayılı Belediye Kanunu, 2005: 14)

Görüldüğü üzere belediyeler doğru idare edilmeleri halinde, bir kentin ihtiyaç duyduğu birçok hizmetin yerine getirilmesi için oldukça geniş yetkilerle donatılmışlardır. Bununla birlikte belediyelerde yönetim kademesinde dikey ve yatay bir hiyerarşi söz konusudur. Başkandan aşağı doğru inen sıralama dikey hiyerarşiyi oluştururken; başkan haricinde diğer birimler kendi sınıflarında yatay hiyerarşiyi oluşturmaktadırlar (Bkz. Tablo 3).

Tablo 3: Türkiye Belediyelerinde Üst Kademe Yönetim Şeması

II ve İlçe Belediyeleri

Belediye Başkanı

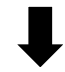

Başkan Yardımcıları

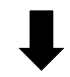

Müdürler
Büyükşehir Belediyeleri

Belediye Başkanı

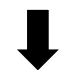

Genel Sekreter ve Yardımcıları

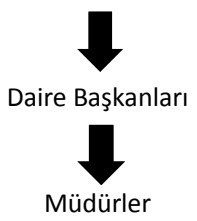

Bu hiyerarşi üzerinden çalışmaları organize edilen belediyelerde, üst kademe yöneticilerinin liderlik vasıfları belediye örgütlenmesini etkin bir şekilde idare etmelerini sağlarken; mesleki bilgi kapasiteleri ise kente yönelik hizmetleri nitelikli bir şekilde üretmelerini sağlamaktadır. Daha net bir ifadeyle belediyenin kendi organizasyonel yapısı ve de kent, belediye üst kademe yöneticilerinin liderlik ve mesleki bilgi kapasitelerinden doğrudan etkilenmektedir. Dolayısıyla çalışmanın bundan sonraki kısmında liderlik ve mesleki eğitim kavramları ele alınmaktadır. 


\section{Liderlik Kavramı}

Liderlik kavramı insanlığın tarihi kadar eskidir ve en temelinde insanların davranışlarını etkileyebilmek üzerinden açıklanmaktadır. Bir kişi eğer diğer insanların davranışlarını başka insanlardan daha çok etkileyebiliyorsa, liderlik gücü de o noktada ortaya çıkmaktadır (Stogdill, 1974: 3-18; Yukl, 2010: 21). Sosyal bir varlık olan insan, sosyal bir yaşam tarzı meydana getirdiğinden itibaren gruplaşma ve taraf olma eğiliminde olduğundan dolayı, kendi içerisinden liderlik edecek kişilere ihtiyaç duymuştur. Liderlik kavramı ilk başlarda ve uzunca bir süre tanrının seçimi ve lütfu olarak görülmüş, sorgulanmayan ve doğrudan itaat edilen bir anlam yüklenmiştir. Fakat daha sonraları sosyal yaşamda ortaya çıkan yeni hedeflerle birlikte liderlik kavramının sorgulanabilir ve geliştirilebilir bir kavram olduğu kabul görmeye başlamıştır. Günümüzde insanlara bağlı ortaya çıkan organizasyonların daha karmaşık hale gelmeleri ise, özellikle farklı liderlik yaklaşımlarının ortaya çıkmasında oldukça etkili olmuştur. Artık tek tip bir liderlik anlayışından ziyade, organizasyonun özelliklerine ve amaçlarına göre liderlik tarzları ortaya konulmaktadır (Özkan, 2016: 616-617).

\subsection{Liderliğin Güç Kaynakları}

Insanın olduğu her yerde bir amaç ve organizasyon mevcuttur ve dolayısıyla insanları yönlendiren ve onların davranışlarını etkileyen liderler de insanın olduğu her yerde bulunmaktadırlar. Burada liderlik meşruiyetinin ve gücünün nereden geldiği konusu ortaya çıkmaktadır. Liderliği oluşturan ve onun diğerleri tarafından kabul edilmesini sağlayan güç kaynakları şu şekilde sıralanabilir (Korkmaz, 2017: 13-15);

- Yasal Güç: Belirli bir kanuni metinden ortaya çıkan yaptırım yetkisine bağlı olarak bir kişinin sahip olduğu güçtür. Burada liderin taleplerini yerine getirmeyen kişiler yasanın dışına çıkmış sayılacaklarından dolayı ceza alma tehlikesiyle karşı karşıyadırlar ve lidere uymak zorundadırlar. Yasal güç kaynağında liderin kişisel yeteneklerinin ve donanımın bir önemi bulunmamaktadır. Lider tüm gücünü içinde bulunulan organizasyonun yaptırım gücünden almaktadır.

- Ödüllendirme Gücü: Belirlenmiş başarılara ulaşılması halinde, liderin ödül vermesi üzerinden sağlanan güç kaynağıdır. Burada lider, vaat ettiği ödüle göre diğerlerini motive etmekte ve yönlendirmektedir. Maaş artışı, takdir etme, pozisyonunu yükseltme ve iş yükünü hafifletme gibi çeşitli ödüller lider tarafından kullanılmaktadır. Lider gücünü zorlama üzerinden değil, daha çok yönetilenlerin gönüllülüğü üzerinden almaktadır.

- Zorlayıcı Güç: Liderin doğrudan diğer insanları zorlaması ile ortaya çıkan güç kaynağıdır. Lider burada hem doğrudan hem de dolayı bir şekilde zor kullanabilmektedir. Bu zorlama can ve mal güvenliğini tehdit etmek gibi gayri meşru bir şekilde olabileceği gibi; işten atma, toplumdan uzaklaştırma, ceza verme gibi kendisine tanına yetkiler üzerinden meşru yöntemlerle de ortaya konulabilmektedir.

- Karizmatik Güç: En etkin güç kaynaklarından birisi olarak nitelendirilmektedir. Lider burada tamamen kendi kişiliği ve yetenekleri üzerinden diğerlerini etkisi altına almakta ve yönlendirmektedir. İnsanları motive ederek, kendi istekleri ile en üst seviyede hizmet etmelerini sağlamakta bu güç kaynağı oldukça etkilidir. Karizmatik liderlikte yönetilenler açısından biat etme en üst seviyeye çıkarken, sorgulama da en alt seviyeye inmektedir.

- Uzmanlık Gücü: Lider burada gücünü kendi mesleki donanımından almaktadır. Belirli hedefler için bir araya gelmiş kişiler, liderin sahip olduğu bilgi birikimi ile hedeflerine ula- 
şacaklarına inandıklarından dolayı ona tabi olmaktadırlar. Bu güç kaynağında lider, diğerlerinden fazla oranda sahip olduğu bilgisiyle kendisini meşru hale getirmektedir.

\subsection{Liderin Yöneticiden Farkı}

Genel anlamda lider ve yönetici aynı görülse de aralarında önemli farklar bulunmaktadır. Lider kendi vasıflarıyla hükmetme gücünü elde ederken; yönetici kendisine başkaları tarafından verilen yetki ile bu gücü elde etmektedir. Ayrıca liderin başarısı hedeflere ulaşma üzerinden ölçülürken, yöneticinin başarısı kâr marjı üzerinden ölçülmektedir. Bir başka deyişle yönetici, organizasyonu sürdürebildiği oranda başarılı kabul edilirken; lider ise organizasyonu hedefe ulaştırıp ulaştıramadığı üzerinden değerlendirilmektedir. Bunların yanında yönetici, bir organizasyonda görevlendirilmeye ihtiyaç duyarken; lider bu organizasyonu kendisi inşa etmektedir. Dolayısıyla etkileme yeteneği sayesinde lider güç ve otoriteyi kendisini izleyenlerden alırken; yönetici bu gücü kendisini oraya getirenlerden almaktadır. Lider ve yöneticinin arasındaki temel bir diğer farklılık da kendilerine tabi olanlardan gelmektedir. Lideri takip edenler için bir zorunluluk söz konusu değilken, yöneticiyi takip edenler açısından böyle bir serbestlik yoktur. Bunun sebebi lideri takip edenleri, liderin kendi yetenekleri bir araya getirirken; yönetici hâlihazırda var olan bir topluluğun başına getirilmektedir (Bertocci, 2009: 9-11). Lider ve yöneticinin farklarını Tablo 4'de daha detaylı olarak görmek mümkündür;

Tablo 4: Lider ve Yöneticinin Farkları

\begin{tabular}{cc} 
Yöneticinin Özellikleri & Liderin Özellikleri \\
Var olanı yönetir. & Var olanı yeniler. \\
Başkalarından kopyalar. & Orijinallik ortaya koyar. \\
Var olanı korur. & Var olanı geliştirir. \\
Sistemlere ve yapıya odaklanır. & İnsanlara odaklanır. \\
Kontrol altında tutmaya çalışır. & Güven ruhunu geliştirir. \\
Kısa vadeli bakış açısına sahiptir. & Uzun vadeli bakış açısına sahiptir. \\
"Nasıl" ve "ne zaman" sorularını sorar. & "Ne" ve "niçin" sorularını sorar. \\
Önüne bakar. & Ufka bakar. \\
Taklit eder. & Yaratır. \\
Statükoyu kabul eder. & Statükoya meydan okur. \\
Emir eridir. & Kendine buyruktur. \\
Işleri doğru yapar. & Doğru işi yapar. \\
\hline
\end{tabular}

Kaynak: (Luthans, 2011: 415)

Fakat burada yöneticiliğin olumsuz, liderliğin ise daha olumlu bir kavram olduğu sonucuna varılmamalıdır. Her organizasyon ve topluluk amaçlarına uygun bir şekilde bazen liderlere, bazen de yöneticilere intiyaç duyabilmektedir. Eğer risk alınarak büyük aşamalar kaydedilmesi gerekiyorsa liderlik; aksi halde mevcudun korunması ve daha temkinli bir gelişim hedefleniyorsa da yöneticilik ön plana çıkmaktadır. Bunun yanında artık organizasyonlar daha yoğun bir rekabet ortamında uzun vadeli hedeflere yöneldiklerinden, değişimi yaratma ve sürdürme becerisine sahip olan liderlik yaklaşımları bir zorunluluk haline gelmiştir denebilir. Tüm bu güncel gelişmeler liderliğin yöneticilik karşısında daha ön plana çıkmasına sebep olmaktadır (Bozlağan, 2005: 29-30). Burada dikkat edilmesi gereken bir diğer husus da her lider yönetici olabilir, fakat her yönetici lider olamaz. Bunun sebebi liderin diğer insanlardan ayrılan mezi- 
yetlere sahip olmasıdır. Bunlara ek olarak doğru bir liderin sahip olması gereken temel nitelikleri şu şekilde derlemek mümkündür (Oplinger vd., 2016: 67-74; Zaccaro vd., 2001: 453-476; Spears, 2010: 25-30; Vesso ve Alas, 2016: 306-317);

Tablo 5: Liderde Bulunması Gereken Özellikler

\begin{tabular}{|c|c|c|c|}
\hline Adalet sağlama & Minnet duyabilme & Sadık olabilme & Hizmet edebilme \\
\hline Cesur olabilme & Öğretebilme & Meraklı olma & Danışabilme \\
\hline Doğru sözlü olma & Kendine güvenme & Duygularını dizginleme & Hatiplik \\
\hline Empati yapabilme & Sorumluluk üstlenebile & Organize edebilme & Güvenebilme \\
\hline Etik olabilme & Örnek olabilme & Yaratıcılık & Sezebilme \\
\hline Etki kurabilme & Problem çözebilme & Esneklik & Ceza verebilme \\
\hline Güven verme & Merhametli olma & Fırsatları görebilme & Kendini adama \\
\hline Hedef belirleyebilme & Kişilikli olma & Karşı koyabilme & Yetenekleri keşfetme \\
\hline Hesap verebilme & Dinleyebilme & Olgunluk & Sözünde durma \\
\hline Illetişim kurabilme & Duyarlı olma & Zamanı yönetebilme & Heyecan uyandırabilme \\
\hline İşbirliği yapabilme & Cömertlik & Açık fikirlilik & Tevazu gösterebilme \\
\hline Kendini geliştirebilme & Doğru yorumlayabilme & Tutarlı olabilme & Tutkulu olabilme \\
\hline Motive edebilme & Odaklanabilme & Geri adım atabilme & Vizyon oluşturabilme \\
\hline Öncü olma & Ödül verebilme & İddialı olma & Yaratıcı olabilme \\
\hline Pozitif olma & Güven verme & Sabırlı olma & Umut verebilme \\
\hline Problem çözebilme & Karizmatik olma & Anlaşma yapabilme & Yorulmama \\
\hline Stratejik düşünebilme & Tarafsız olma & Risk yönetebilme & Bencil olmama \\
\hline Ekip oluşturabilme & Yetki devredebilme & Saygı gösterebilme & Sınırlarını bilme \\
\hline Moral verme & Çalışkan olma & Disiplinli olma & Eser bırakabilme \\
\hline Takipçileri geliştirme & Fark edilir olma & Perspektif geliştirebilme & Değer yaratabilme \\
\hline
\end{tabular}

\subsection{Liderlik Yaklaşımları}

Liderlik yaklaşımları, liderlerin sahip oldukları özelliklerin tespit edilmesinde ve liderlik davranışlarının yorumlanmasında kullanılan bakış açılarıdır. Bu kapsamda liderlik yaklaşımları üç ana başlık altında toplanmaktadır.

- Özellikler Yaklaşımı: Liderliğin bilimsel olarak analizi ilk olarak özellikler yaklaşımı ile başlamıştır. Burada liderlerin sahip oldukları fiziksel ve kişisel özellikler evrensel boyutta ortaya konulmaya çalışılmıştır. Fakat bu çalışmalarda ortaya konulan veriler uzun soluklu olmamış ve büyük oranda kabul görmemişlerdir. Bunun sebebi liderlerin sahip oldukları zekâ, bilgi, kendine güven, dürüstlük, güzel görünme, uzun boylu olma, enerjik olma, ahlaklı olma ve diğer özelliklerin ölçülmesinin tam anlamıyla mümkün olmamasıdır. Bu kapsamda liderleri sahip oldukları özelliklere göre betimleyen bu görüş zaman içerisinde geri planda kalmıştır (Luthans, 2011: 419-420).

- Davranışlar Yaklaşımı: Özellikler yaklaşımının liderleri tanımlamada yetersiz kalmasından dolayı bu yaklaşım üzerine yoğunlaşılmıştır. Davranışlar yaklaşımıyla liderlerin sergilemeleri gereken davranışlar belirlenmeye çalışılmış ve çeşitli davranış sınıflandırmaları yapılmıştır. Michigan Üniversitesinde 1947 'de yapılan çalışma ile iş merkezli ve kişi merkezli 
davranışlar incelenmiştir. İş merkezli davranışlar yaklaşımında, hedefe varmak liderin temel amacı olarak belirlenmiştir. Bunun için lider ödül ve ceza gibi yetkilerini kullanabilmektedir. Kişi merkezli davranışlar yaklaşımında ise liderin ekibi ile iletişim kurabilmesi, onları motive etmesi, yeteneklerini ortaya çıkartması, arkadaşlık ve dostluk bağlarını geliştirmesi gibi davranışlar belirlenmiştir. Burada lider, çalışanların tatminine odaklanarak performansı geliştirmeyi hedeflemektedir. Bu dönemde Ohio State Üniversitesi'nde de liderin işe ve çalışanlara yönelik davranışlarını ölçen anket çalışmaları yapıımıştır. Bu çalışmalar sırasında işe yönelik yoğunlaşan liderlikte sonuca odaklanıldığı ve bu yönde katı bir yapılanma tesis edildiği gözlemlenirken; çalışana yönelik lider davranışında ise arkadaşlık kurma, karşııkı ıüven oluşturma, sıcaklık ve uyum geliştirme gibi pozitif davranışların liderler tarafından sergilendiği gözlemlenmiştir (Bertocci, 2009: 28-30).

Her liderin kendisini lider yapan özellikleri olmasına rağmen, kendisini diğer liderlerden ayıran yönetme tarzı da bulunmaktadır. Bazı liderler doğrudan hükmetmek isterken, bazıları birlikte yönetmeyi tercih edebilmektedir. Burada içinde bulunulan koşullar, yetkiler, amaçlar ve ekibin bu duruma yaklaşımı gibi etmenler bir zemin hazırlamaktadır. Bu kapsamda en temelinde üç temel liderlik davranışı bulunmaktadır;

- Otokratik Liderlik: Bu liderlik tarzında tüm yetki, karar alma ve uygulatma gücü sadece liderde bulunmaktadır. Lider burada kendi yetkilerini ve yaptırım gücünü başkaları ile paylaşmamaktadır. Kısacası liderin dediği her şey yerine getirilmekte ve sorgulanmamaktadır (Önen ve Kanayran, 2015: 46). Lider burada cezalandırma gibi zorlayıcı gücünü de kullanabilmektedir. Otokratik liderlik her ne kadar adı ve tanımlaması ile olumsuz görülse de içinde bulunulan şartlara göre olumlu getirileri de olabilmektedir. Özellikle kriz dönemlerinde; dağınık, motivasyonu düşük ve birlikteliğini kaybetmiş organizasyonlarda süreçlerin toparlanması için başvurulan bir tarz olabilir.

- Demokratik Liderlik: Lider burada demokratik bir anlayışı örgüt kültürü haline getirmeye çalışmaktadır. Kendisiyle birlikte astlarının ve diğer örgüt mensuplarının karar alma süreçlerinde yer almaları için hem onlara fırsat vermektedir hem de onları motive etmektedir (Bakan ve Büyükbeşe, 2010: 75). Bu yaklaşımın benimsendiği liderlikte cezadan daha çok ödül verme ve fikirlere değer verme söz konusudur. Demokratik liderlik kriz zamanlarında sorunların derinleşmesine sebep olsa da normal şartlar altında daha çok fikrin ortaya konulmasını ve örgüt üyelerinin çalışmaları daha çok sahiplenmelerini sağlayabilir.

- Serbestiyetçi Lider: Lider burada yetkilerini büyük oranda diğerlerine devretmekte ve olabildiğince sorumluluk almamaktadır. Bir başka deyişle liderlik pozisyonunda bulunan kişi yönetmekten ziyade, sorumlulukları dağıtarak bir koordinatörlük yapmaktadır. Dolayısıyla bu tarzı benimseyen lider, karar almak ve kendi amaçlarına ulaşmak için diğerlerine bağımlı konumdadır. Grup burada kendisini yönetmekte ve lideri yönlendirmektedir (ibicioğlu vd., 2009: 6). Bu liderlik tarzında grup üyeleri liderden daha ön plana çıktıklarından; kendilerini geliştirmeleri, daha rahat görüş bildirmeleri, kendi içlerinde işe yönelik gruplaşabilmeleri ve 
yeni fikirler üretebilmeleri mümkün hale gelebilmektedir. Tüm bu liderlik davranışlarıyla ilgili olarak işleyişsüreçlerini Tablo 6 üzerinden okumak mümkündür.

Tablo 6: Liderlik Davranışlarının Yansımaları

\begin{tabular}{cccc}
\hline Eylem & Otokratik Tarz & Demokratik Tarz & Serbestiyetçi Tarz \\
\hline $\begin{array}{c}\text { Amaç } \\
\text { Belirleme }\end{array}$ & Sadece lider karar verir & Astların görüşü alınır & İlgili herkesin görüşü alınır \\
Karar Alma & Astların katılımı yoktur & Astlara danışılır & Tüm kademeler süreçlere dâhil \\
edilir
\end{tabular}

Kaynak: (Özsalmanlı, 2005: 139'dan uyarlanmıştır.)

- Durumsallık Yaklaşımı: Özellikler ve davranışlar yaklaşımında liderlik tarzları yeterli seviyede yorumlanamadığı için, ilerleyen yıllarda durumsallık yaklaşımı geliştirilmiştir. Bu yaklaşımda temel bakış açısı liderliğin bulunulan ortama ve amaçlara göre değiştiğidir. Durumsallık yaklaşımında lider, içinde bulunulan koşullara, amaçlara ve sahip olunan imkânlara göre davranışlar ortaya koymaktadır. Bu yaklaşımın varsayımına göre tüm koşullar için geçerli tek bir liderlik biçimi yoktur. Her koşul ve ortam kendisine özel liderlik tarzlarına ihtiyaç duymaktadır. Bu kapsamda durumsallık yaklaşımına etki eden dört temel etmen bulunmaktadır (Bertocci, 2009: 34);

- Liderin kişisel özellikleri: Liderin sahip olduğu teknik yetenekleri, motive etme gücü, geçmiş tecrübeleri, vizyonu, sorumluluk bilinci, iş önceliklerini belirleyebilme gibi özelliklerden oluşmaktadır. Burada lider ile ekip arasındaki ilişkiler iyi ise lider için olumlu; bu ilişkiler kötü ise lider için olumsuz bir durum söz konusudur. Daha net bit ifadeyle liderin kişisel özellikleri, ekip ile olan ilişkisine etki edebilmektedir.

- Iş̧in özellikleri: İşin karmaşa veya rutinlerden oluşması durumudur. İşi gerçekleştirmeye yönelik yöntemler belirliyken ortam lider için daha iyi; bu yöntemler belirsizken ortam lider için daha olumsuzdur.

- Organizasyon yapısı: Organizasyonun politikası, kuralları, kaynakları ve motivasyonu lider için çeşitli olumlu veya olumsuz koşullar sağlamaktadır.

- Takipçilerin nitelikleri: Takipçilerin ihtiyaçları, beklentileri, yetenekleri, motivasyonları, kişilikleri ve diğer özellikleri lider için olumlu veya olumsuz bir ortamı sağlamaktadır.

\subsection{Liderlikte Modern Yaklaşımlar}

Liderlik yaklaşımı, liderlik davranışından farklı olarak; bir liderin kendi yönetme vizyonunu ifade etmektedir. Her liderin kendine ve örgütüne yüklediği anlam üzerinden belirlediği yönetme anlayışı bulunmaktadır. Bu kapsamda beş temel liderlik yaklaşımından bahsetmek mümkündür; 
Karizmatik Liderlik: Burada lider tüm yönetme gücünü ve meşruiyetini kendi karizmatik yeteneklerinden almaktadır. Fakat bu karizma sıfatı lidere kendisi tarafından değil, takipçileri tarafından verilmektedir. Takipçiler açısından karizmatik gördükleri bir liderin ardına düştüklerinden dolayı bir gönüllülük de ortaya çıkmaktadır. Dolayısıyla karizmatik liderler, takipçileri tarafından en çok bağııık ve itaat gören kişilerdir. Bunun yanında karizmatik liderin ihtiyaç duyduğu bazı bileşenler mevcuttur; çevre tarafından onaylanma, ilham verici yeni bir vizyona sahip olma, mevcut statüye alternatif olma, alışılmadık olma, amacıyla ilgili tutkulu olma, mevcudu değiştirme konusunda alışılmadık yöntemleri kullanabilme, takipçilerde yüksek beklentiler oluşturabilme, uzmanlık ve yetenekler bakımından benzersiz bir kişilik ortaya koyabilme gibi özellikler burada sayılabilir (Conger ve Kanungo, 1998: 48-51). Karizmatik liderler ayrıca üye ihtiyaçlarına duyarlılık gösterme, çevresel etkenleri iyi okuyabilme, sıra dışı davranışlar sergileme, risk üstlenebilme gibi özelliklere de sahiptirler (Arıkan vd., 2017: 5-6). Karizma gibi, kişiyi diğerlerinden ayıran ve onun adeta bir kahraman gibi görülmesini sağlayan özellik; karizmatik liderlerin diğer tüm liderler arasından sıyrılmalarını sağlamaktadır. Karizmatik liderliğe ilişkin olarak olumlu ve olumsuz yönler şu şekilde belirtilebilir (Nikoloski, 2015: 1926; Sparks, 2014: 3-9; Flynn ve Staw, 2004: 311-313);

- Olumlu Yanları: Örgütü içinde bulunduğu krizden çıkartabilir, örgüte yeni bir vizyon kazandırabilir, dağılmış olan örgütü yeniden toparlayabilir, örgütü hedeflenen başarıya daha kısa sürede ulaştırabilir, örgüt dışındaki diğer kesimlerin de desteğini alabilir, örgüte yeni bir heyecan getirebilir.

- Olumsuz Yanları: Zamanla güç zehirlenmesi yaşayabilir, otoriter bir anlayışa yönelebilir, kendisinden sonra örgüt dağılabilir, tüm başarıyı üstlenerek astlarını kırabilir, kendi amaçlarını örgütün önüne koyabilir, diğer karizmatik lider adaylarından rahatsızlık duyabilir, yetki devrinden kaçınabilir, örgütün başarı kapasitesi yalnızca liderin yetenekleriyle sınırlı kalabilir.

Dönüştürücü Liderlik: Dönüştürücü lider mevcut olandan daha farklı hedefler ve yöntemler belirleyerek, ekibini onlara uymaya teşvik etmektedir ve organizasyonda bir dönüşüm gerçekleştirmektedir. Dönüştürücü lider bunu gerçekleştirmek için yetki devri yaparak astlarının yeteneklerini geliştirmeyi hedeflemektedir. Bunun yanında çalışanlarına değer vererek, onları yeni hedeflere ulaşmaları için de yönlendirmektedir. Bu bağlamda dönüştürücü liderlik, liderlik anlayışını da farklı bir noktaya taşımaktadır. Artık ekibin motivasyon kaynağı liderden çok, yeni hedeflere ulaşma gayesidir. Dolayısıyla liderin karizması, dönüştürücü liderin vasıflarından sadece birisidir. Dönüştürücü liderin sahip olduğu temel özellikler; karizma, motivasyon sağlama, entelektüel teşvik ve takipçilere bireysel önem vermektir (Bass ve Riggo, 2005: 4-7). Dönüştürücü liderlik uygulanan örgütlerde ödül beklentisi ön planda değildir. Takipçiler daha çok örgüte bağlanarak hedeflere ulaşmak üzerinden motive olmaktadırlar. Lider burada takipçilerin kişisel amaçlarını, örgütün amaçlarına uydurmaktadır. Bu kapsamda lider yeni bir vizyon oluşturmakta, yeni hedefler ve yöntemler belirleyerek; örgütü bu yönde dönüştürmektedir (Kaygın ve Kaygın, 2012: 30-31). Dönüştürücü liderin çalışma alanı tüm organizasyonu ve süreçleri kapsamaktadır. Hedeflerin yenilenmesi, çalışma şekillerinin yenilenmesi, kullanılan yöntemlerin yenilenmesi, bakış açılarının yenilenmesi ve tüm bunlara ekibin uyum sağlaması dönüştürücü liderliğin amaçları arasındadır. Dönüştürücü liderliğe ilişkin olarak olumlu ve olumsuz yönler şu şekilde belirtilebilir (Odumeru ve Ogbonna, 2013: 356-359; Cavazotte vd., 2013: 492-500); 
- Olumu Yanları: Amacından sapmış organizasyonu yeniden hedefe yönlendirebilir, motivasyonunu kaybetmiş bir örgütte yeniden motivasyon yaratabilir, günün gerisinde kalmış yöntemleri günün koşullarına uydurabilir, başarıya gidecek yeni yollar ortaya koyabilir, ekibe nasıl başarılı olabileceğini öğretebilir, ihtiyaç olan değişimi yaratabilir.

- Olumsuz Yanları: Değişim anlayışı her örgüt tarafından kabul görmeyebilir, durumu olduğundan daha kötü bir noktaya dönüştürebilir, mevcut düzeni bozabilir, örgüt içi uyumu bozabilir, organizasyonu kendisini var eden değerlerinden kopartabilir.

İşlemci Liderlik: İşlemci liderlik, dönüştürücü liderden farklı olarak işlerin aynı seyirde devam etmesine yoğunlaşmaktadır. Bunu yaparken ekip üyelerine ödül ve ceza üzerinden bir motivasyon sağlamaktadır. Bu kapsamda burada bir takas söz konusudur. Lider aldığı hizmet oranında takipçisine ödül verirken; takipçi de yaptığı iş üzerinden ödülünü almaktadır. Dolayısıyla bu liderliğe etkileşimci/yönetici liderlik de denilmektedir. İşlemci lider, ileriye yönelik vizyoner düşünce yaratmak yerine süreçlerle ilgilenmektedir. Bu süreçlerde ekip üyesi sorumluluğunu zamanında ve doğru olarak yerine getirdiği müddetçe ödül almaktadır (Odumeru ve Ogbonna, 2013: 358). İşlemci lider, ekip üyeleri için hedefleri belirlemekte ve aksayan yanları tespit etmek için denetim mekanizması kurmaktadır. Bu liderler iş odaklı çalışmaktadırlar ve belirli işler yolunda gittiği sürece de bir değişimin peşinden gitmemektedirler. Dolayısıyla işlemci lider daha çok yöneticilik özelliği ile çalışmalarını yürütmektedir (Kılıç vd., 2014: 251). Bu sistemde ortada belirlenmiş hedefler bulunmaktadır ve lider sadece bu hedeflere ulaşılması için çalışmalarını yürütmektedir. Böylece yeni bir hedef belirleme ve vizyon ortaya koyma zorunluluğu olmadığı için, karizmatik özelliklere de ihtiyaç duymamaktadır. Elindeki ödül ve ceza yetkisi liderlik edebilmesi için yeterlidir. Lider burada işin yerine getirilip getirilmediğine bakarken, çalışan da aldığı ödüle odaklanmaktadır. Fakat lider burada sadece yönetici gibi çalışmamakta, gerekli durumlarda müdahale de edebilmektedir. Bu liderlikte iki temel yönetim anlayışı bulunmaktadır. Koşula bağı ödüllendirmede; lider ile takipçiler arasında temel olarak hedefe ulaşma ve ödüllendirme süreci söz konusudur ve lider genel olarak takipçi olarak çalışmaları izlemektedir. Fakat istisnalarla yönetimde ise; çalışanlar hata yaptığında, lider gerekli müdahaleleri yapmak için süreçlere dâhil olabilmektedir (Bozlağan, 2005: 43). İşlemci liderliğe ilişkin olarak olumlu ve olumsuz yönler şu şekilde belirtilebilir (McCleskey, 2014: 122125; Judge ve Piccolo, 2004: 755-765);

- Olumlu Yanları: Örgüt dengeli bir şekilde hedeflerine ulaşabilir, süreçler ve hedefler belirli olduğu için olumsuz durumların yaşanma oranı düşebilir, sorumluluğunu yerine getirenler ödüllerini düzenli alabilirler, iş yükü ve ödül belli olduğu için anlaşmazlık ortamının meydana gelmesi bertaraf edilebilir.

- Olumsuz Yanları: Liderden gerekli vizyon ve dönüşüm katkısı görülmeyebilir, çalışanlar üzerinde ekstra motivasyon yaratmak için lider bir çaba sarf etmeyebilir, örgütü ve organizasyonu olduğundan daha ileriye götürmek için lider sorumluluk almayabilir.

Hizmetkâr Liderlik: Hizmet etmek ve liderlik etmek en temelinde birbirleri ile zit kavramlar olarak algılanabilirler. Fakat eğer bir kişi organizasyonuna hizmet ederek katkı sunmak isterse ve bunun için de o organizasyona liderlik etmesi gerekiyorsa, burada hizmetkâr liderlik ortaya çıkmaktadır. Hizmetkâr liderlerin sahip oldukları bazı özellikler şu şekilde sıralanabilir; dinleme, empati yapma, ilişkileri iyileştirme, farkında olma, ikna edebilme, kavramsallaştırma, öngörü sahibi olma, idare etme, diğerlerini geliştirme ve topluluk inşa etme. Hizmetkâr liderlikte bulunan hizmet etme isteği birçok ekip üyesinde bulunabilir. Fakat zamanla bu hizmet etme işini yöneterek yerine getirebileceğine inananlar hizmetkâr lider olmaktadırlar (Spears, 
2010: 26-29). Hizmetkâr liderliği diğerlerinden ayıran en temel özellik; "önce insan ve önce hizmet etmek" anlayışını ortaya koymasıdır. Böylece lider hizmet bekleyen değil, hizmet eden konuma geçmektedir. Bu kapsamda lider, organizasyonun ihtiyaçlarını kendi ihtiyaçlarının önüne koymaktadır. Hizmetkâr liderler için güç, para, şöhret ve mevki öncelikli hedefler arasında değildir. Onlar için tek gaye organizasyonu olumlu yönde geliştirmektir. Burada lider kendisini değil, diğerlerini düşünmektedir (Balay vd., 2014: 230-231). Hizmetkâr liderin bulunduğu organizasyonlarda derin bir kendini adanmışlık ortaya çıkmakta ve bu duygu bütünlüğü organizasyonun diğer üyelerine de yayılmaktadır. Hizmetkâr liderliğe ilişkin olarak olumlu ve olumsuz yönler şu şekilde belirtilebilir (Ingram, 2016: 22-25; Russel ve Stone, 2002: 145-154);

- Olumlu Yanları: Kurum içi işbirliği ve huzur ortamı gelişebilir, hizmet bilinci ortaya çıkabilir, kişisel hırslar bertaraf edilebilir, işbirlikleri daha rahat gelişebilir, kendini adayan takipçi sayısı artabilir, karşılıklı güven duygusu gelişebilir.

- Olumsuz Yanları: Heyecan ortadan kalkabilir, liderin karizma ortaya koymayışı takipçilerde motivasyonsuzluk yaratabilir, ödül mekanizması olmayışı sorun olabilir, önemli ve radikal kararlar alınamayabilir, ihtiyaç olan değişimlerin ortaya konulması mümkün olmayabilir.

Stratejik Liderlik: Bu liderlik tarzında lider sadece bir vizyona sahip olmakla yetinmemekte; bu vizyona ulaşılmasını sağlayacak stratejileri de hayata geçirmektedir. Stratejik lider bu kapsamda mevcudu koruma eğiliminden çok geleceğe odaklanmakta; buna uygun kısa ve uzun vadeli stratejiler geliştirmektedir. Lider için burada temel amaç belirlenen hedefe ulaşmaktır. Dolayısıyla stratejik liderler, aynı zamanda geleceği tasarlama gayretinde olan kişilerdir. Bu vizyona sahip olan lider çevresini çok iyi bir şekilde gözlemlemekte, şartları tüm gerçekçiliği ile tespit ederek, hedefe ulaşmak için gerekli stratejileri ortaya koymaktadır (Quong ve Walker, 2010: 23-24). Stratejik liderler örgütün tüm süreçlerine eğilmemekte, daha çok hedefe ulaşmak için gerekli stratejileri oluşturmakla ilgilenmektedirler. Bu yönüyle stratejik liderlik örgütün üst kademesinde gerçekleştirilmektedir. Burada lider, değişen çevresel koşulları doğru okumaya yoğunlaşmakta, hedefe ulaşmak için oldukça cesur ve radikal kararlar alabilmektedir. Dolayısıyla liderin temel amacı hedefi belirleyerek ona ulaşabilmektir (Uğurluoğlu ve Çelik, 2009: 127-128). Stratejik liderlik günümüzün yoğun rekabet gerektiren ortamında en öne çıkan liderlik vizyonlarından birisi olarak görülebilir. Artık temel yöneticilik anlayışları birçok alanda yetersiz kaldığından; çevresini okuyabilen, hedefleri doğru belirleyen, süreçleri planlayabilen ve bunlara uygun stratejik planlamalar yapabilen liderlik tarzlarına ihtiyaç duyulabilmektedir. Stratejik liderliğe ilişkin olarak olumlu ve olumsuz yönler şu şekilde belirtilebilir (Quong ve Walker, 2010: 23-32; Davies and Davies, 2004, 30-37);

- Olumlu Yanları: Çevresel etmenleri doğru okuyabilir, ulaşılabilecek hedefler belirleyebilir, vizyonu net bir şekilde ortaya koyabilir, hedefe ulaşmak için gerekli stratejik planlamaları yapabilir, amaçlara ulaşma olasılığı yüksek olabilir, takipçilerini motive etmesi kolay olabilir, günün gereklerine göre stratejileri yenileyebilir, neden sonuç ilişkisini doğru bir şekilde kurabilir.

- Olumsuz Yanları: Sadece üst yöneticilik süreçlerine yoğunlaşabilir ve alt yönetim süreçlerini göz ardı edebilir, takipçileriyle yeteri kadar ilgilenmeyebilir, hedefe ulaşmak için temel değerlerden kopabilir, sonuca odaklandığından dolayı takipçilerin fikirlerini göz ardı edebilir, fazla duygusuz davranabilir, hedefe ulaşmak için her yolu meşru görebilir. 


\subsection{Liderlik Kavramının Belediyeler Açısından Önemi}

Türk yerel yönetim sisteminde belediyeler açısından güçlü başkan, güçsüz meclis modeli hâkimdir. Belediye başkanı, belediye teşkilatının başı olarak belediyeyi sevk ve idare etmektedir. Bunun yanında belediyelerde başta başkan olmak üzere, başkan yardımcıları, genel sekreterler, genel sekreter yardımcıları, daire başkanları ve müdürler de belediyeyi yöneten aktörlerdir. Dolayısıyla belediyelerde önemli bir yönetici teşkilatlanması bulunmaktadır. Ayrıca siyasi bir kurum olan belediyelerde başkanın seçimle iş başına gelmesi; en temelinde farklı liderlik becerilerinin ve yöneticilik vasıflarının kentin çıkarı için denenmesi ihtiyacındandır. Halk burada kentini en iyi idare edecek kişiyi seçmeye çalışmaktadır. Bu sebeple belediye başkanının ve diğer üst kademe yöneticilerinin sahip oldukları liderlik vasıfları, belediye teşkilatının doğru yönetilmesi için bir gereklilik olarak görülebilir. Bu kapsamda liderlik vasıflarına haiz olmayan bir idarecinin, ekibini etkin bir şekilde oluşturması ve yönetmesi mümkün olamayacağından; liderlik vasfı tüm idareciler için bir zorunluluk olarak karşımıza çıkmaktadır. Dolayısıyla yönetmesi ve değişim yaratması amacıyla seçilen belediye başkanlarının ve buna bağlı olarak da başkanlar tarafından seçilen diğer idarecilerin sahip oldukları liderlik kapasitelerinin geliştirilmesi, belediyelerin daha etkin yönetilmeleri için faydalı olabilecektir. Bunların yanında, liderlik kavramı içerisinde yukarıda anlatılan içeriğe ilave olarak, kişinin liderlik kapasitesine katkı sağlayacak vizyon ve misyon belirleme, hedef belirleme, ekip oluşturma ve yönetme, etkili iletişim ve hitabet, beden dili, zaman yönetimi ve etik değerler gibi diğer tamamlayıcı bileşenlerin de belediye üst kademe yöneticilerine kazandırılması düşünülebilir. Böylece genel bir perspektiften liderlik kavramı alt bileşenleriyle birlikte değerlendirilmiş olacaktır.

\section{Mesleki Eğitim Kapsamında Hizmet İçi Eğitim}

Hizmet içi eğitim en temelinde; bir kurumda çalışanların işlerini öğrenmeleri ve daha iyi yapmaları için aldıkları mesleki eğitimdir. Dolayısıyla bir kişiye işiyle ilgili temel mesleki bilginin kazandırılması, hizmet içi eğitim yöntemiyle sağlanmaktadır. Hizmet içi eğitim, çalışanın pozisyonu fark etmeksizin görevi süresince belirli dönemlerde alması gereken bir eğitim olarak görülmektedir. Kişi göreve başladığı ilk andan itibaren, temel iş süreçlerini ve işiyle ilgili diğer yenilikçi yaklaşımları en verimli olarak hizmet içi eğitimlerle edinebilmektedir. Özellikle hızla değişen ekonomik, sosyal, teknolojik ve teknik gelişmeler; hizmet içi eğitimin önemini her geçen gün daha da arttırmaktadır. Günün gerekli koşullarını yerine getirebilen ve geleceğe de hazır olan çalışanların yetiştirilmesi için bu mesleki eğitimlere başvurulmaktadır (Görmüş ve Kâhya, 2014: 38-39).

\subsection{Hizmet İçi Eğitimin Hedefleri}

Hizmet içi eğitimle birlikte, kişi göreve başladığı ilk andan itibaren, görevden ayrıldığı ana kadar işiyle ilgili olarak geliştirilmeye çalışımaktadır. Bu yaklaşıma göre bir kurumda çalışanlar ne kadar donanımlıysa, o kurumun başarılı olması da o oranda mümkündür. Bu kapsamda hizmet içi eğitimin hedefleri şu şekilde sıralanabilir (Öztürk ve Sancak, 2012: 763-764);

- Işse yeni başlayan kişinin kuruma uyumunu sağlamak;

- Çalışan kişiye kurumun amaç ve ilkelerini öğretmek;

- İşin gerektirdiği temel mesleki eğitimi çalışanlara sağlamak;

- Çalışana dikey ve yatay geçiş imkânı sağlayacak mesleki eğitimi vermek;

- Teknoloji, sosyal ve diğer alanlardaki gelişmelere çalışanın uyumunu sağlamak;

- Kurumun ürettiği mal veya hizmetteki verimliliği arttırmak; 
- Çalışana mesleki sorunları çözme kabiliyeti kazandırmak;

- Çalışanı yeni sorumluluklar almaya hazır tutmak;

- Çalışanın görevi, yetkisi ve sorumluluğu konusunda farkındalığını arttırmak;

- Zaman, malzeme ve enerji tasarrufu sağlamak;

- İşle ilgili kazaların ve sorunların önüne geçmek;

- Çalışanın moralini ve kendine güvenini arttırmak;

- Kurumun her kademesinde işini bilen kişiler meydana getirmek;

- Kurumda açıklık ve güven ortamı geliştirmek;

- Kurumsal politikanın anlaşımasını sağlamak;

- Karar alma ve sorun çözme kapasitesini geliştirmek;

- Değişime ayak uydurmayı kolaylaştırmak.

\subsection{Hizmet İçi Eğitimin Uygulama Türleri}

Hizmet içi eğitim sadece tek bir yöntemle ve tek bir amaçla uygulanmamaktadır. İşin niteliğine ve çalışanın pozisyonuna göre uygulanması gereken farklı şekilleri mevcuttur. Bu sebeple hizmet içi eğitimin türlerini şu şekilde sıralamak mümkündür (Demirtaş, 2010: 44);

- Oryantasyon Eğitimi: Çalışmaya yeni başlayan bir kişiye verilen temel işe alıştırma ve iş öğretme eğitimidir. Burada kişiye kurumun hedefleri, işin gerekleri, kişinin sorumlulukları ve çalışma şekli öğretilmektedir.

- Temel Eğitim: Görevinde yeni çalışmaya başlayan bir kişiye, bu aşamada işin temel prensipleri, amaçları ve sorumlulukları öğretilmektedir. İşle ilgili temel teknik bilgiler de bu aşamada kişiye gösterilmektedir.

- Geliştirme Eğitimi: Hâlihazırda çalışmakta olan kişiye, işini ve kendisini geliştirmesi için eğitimlerin verilmesidir. Böylece kişinin o işle ilgili uzmanlığının ve yenilikçi bakış açısının geliştirilmesi hedeflenmektedir.

- Yükselme Eğitimi: Hâlihazırda çalışan bir kişinin, daha üst pozisyonlara hazırlanması için verilen eğitimdir. Burada kişi yeni pozisyonun gerektirdiği bilgi ile donatılmaktadır.

- Ö̈zel Alan Eğitimi: Çalışan kişiye eğer özel bir sorumluluk verilecek ise, bu yeni işiyle ilgili bilginin kendisine aktarılmasıdır. Burada kişi standart iş gereklerinden ayrı olarak, yapacağı farklı işe yönelik olarak hazırlanmaktadır.

\subsection{Hizmet İçi Eğitimin Zamanlama Türleri}

Hizmet içi eğitimin hangi zamanda verileceği değişkenlik gösterebilmektedir. Eğitimin içeriği ve süresi burada belirleyicidir. Bu kapsamda iki farklı zaman diliminde bu eğitimler verilebilmektedir (Peker, 2010: 11-12);

- Mesai Iç̧inde Hizmet Iç̧i Eğitim: Çalışan kişi işinin başındayken ve işini yaparken mesleki eğitim alabilmektedir. Böylece çalışana mesai saatleri içerisinde bir eğitim verilebilmektedir.

- Mesai Dışında Hizmet Içi Eğitim: Çalışan kişi mesaisini geçirdiği zaman diliminden ayrı olarak; hafta sonları veya mesai saati bitiminde özel bir eğitime alınabilmektedir. 


\subsection{Hizmet İçi Eğitimin Mekân Türleri}

Uygulanma mekânına göre de hizmet içi eğitimde çeşitlilikler olabilmektedir. Burada ikili bir ayrım bulunmaktadır (Peker, 2010: 12-13);

- Kurum Içinde Hizmet Iç̧i Eğitim: Burada kişi kurumdan ayrı bir yere alınmadan eğitime tabi tutulmaktadır. Bu kapsamda eğitimi kurumun kendi eğitimcileri verebileceği gibi, dışarıdan da eğitimciler gelerek kişiye kendi kurumunda eğitim verebilmektedirler.

- Kurum Dışında Hizmet İ̧̧i Eğitim: Çalışan kişi gerekli görülmesi durumunda kendi kurumundan başka bir yerde eğitime tabi tutulabilmektedir. Genelde farklı kurumdan katılımcıların bir araya geldiği, eğitim için özel hazırlanmış mekânlara ihtiyaç duyulduğu veya uzmanlara bizzat gidilerek eğitim alınması gereken durumlarda bu yöntem uygulanmaktadır.

\subsection{Kamu Kesiminde Hizmet İçi Eğitimin Yasal Dayanağı ve Uygulanışı}

Kamu kesimine yönelik olarak mesleki eğitim iki farklı kurum tarafından verilebilmektedir. Illki özel sektörün profesyonelleri tarafından verilen eğitimlerdir. Burada gelir elde etmek için bir araya gelen profesyoneller ilgili kurumlara eğitimler vermektedirler. İkincisi ise kamu kesiminin kendi uzmanları üzerinden verdiği eğitimlerdir. Türkiye ölçeğinde kamu kesiminde hizmet içi eğitimin verilmesine yönelik temel yasal düzenleme 657 Sayılı Devlet Memurları Kanunu'dur. Kanun uyarınca Devlet Personel Başkanlığı, kamuda hizmet içi eğitime yönelik yönetmelikleri hazırlamakla yetkilendirilmiştir. Bunun yanında Kanun uyarınca, ilgili kurumlar kendi bünyelerinde personellerini eğitmek üzere birimler oluşturmakla görevlendirilmişlerdir. Ayrıca kamu kurumları, kendi personellerini eğitmek üzere yurt dışına gönderme imkânına da sahiptirler (Devlet Memurları Kanunu, 1965: Md. 214-215-216-218).

\subsection{Mesleki Eğitimin Belediyeler Açısından Önemi}

Kentlerin sorunlarının çözülmesi ve daha iyi idare edilmeleri için, ilk sıradaki sorumlu kamu kurumu belediyelerdir. Konuyla ilgili olarak Türkiye özelinde kamu kurumları, bunlara belediyeler de dâhil olacak şekilde, kendi kapasiteleri oranında hizmet içi eğitim vermektedirler. Fakat bu eğitimler büyük oranda mevcut yönetmeliklerin anlatılması ve temel görevleri kapsayacak bir seviyede uygulanmaktadır. Bu sebeple kentlerin sorunlarının günün gereklerine göre çözülmesi ve geleceklerinin doğru bir şekilde oluşturulması ancak geleneksel eğitimin dışında çıkan ve yenilikçi konulara değinen eğitim programlarıyla mümkün olabilir. Bu sebeple hizmet içi eğitim ile yenilikçi ve ufuk açıcı bilgilerin belediye üst kademe yöneticilerine aktarılması; kentlere verilen hizmetin kalitesinde olumlu yönde bir katkı sağlayabilecektir. Konuyla ilgili olarak hem temel mesleki bilgilerin hem de vizyoner ufuk açıcı eğitimlerin bir arada derlenmesi ve belediye üst kademe yöneticilerine aktarılması faydalı olabilir.

\section{Belediye Üst Kademe Yöneticilerinin Eğitim Alma İstekliliklerine Yönelik Bir Saha Araş- tırması}

\subsection{Araştırma Evreni, Örneklem ve Araştırma Yöntemi}

Çalışma kapsamında belediye üst kademe yöneticilerine liderlik ve mesleki eğitimlerin verilmesiyle ilgili olarak; ihtiyaç ve isteklilik durumunu ölçmek amacıyla bir saha araştırması gerçekleştirilmiştir. Araştırma yöntemi olarak tarama modeli kullanılmıştır. Tarama modeli; geçmişte veya mevcutta var olan bir durumu, olduğu şekliyle betimlemekte kullanılmaktadır. 
Burada üzerine araştırma yapılan kişi, kurum veya olay mevcut olduğu haliyle betimlenmektedir (Karasar, 2012: 77). Araştırma kapsamında mevcut durumu tespit etmek amacıyla tümevarım yaklaşımı kullanılmıştır. Tümevarım yaklaşımı; teorik ve uygulamalı bilgi düzeyinin düşük olduğu durumlarda kullanılmaktadır (Bozlağan, 2005: 78). Dolayısıyla araştırma kapsamında bir anket uygulaması yapılmıştır. Araştırma evrenini Edremit Belediyesi'nde görevli üst kademe yöneticiler oluşturmaktadır. Bunlar; başkan (sayısı 1), başkan yardımcıları (sayıları 2) ve müdürlerdir (sayıları 20). Araştırma evreninin oluşturan üst kademe yöneticilerin birimleri Tablo 7'deki gibidir.

Tablo 7: Edremit Belediyesi Üst Kademe Yöneticileri

\begin{tabular}{|c|c|}
\hline Pozisyon & Birim \\
\hline \multicolumn{2}{|c|}{ Belediye Başkanı } \\
\hline \multicolumn{2}{|c|}{ Belediye Başkan Yardımcı } \\
\hline \multicolumn{2}{|c|}{ Belediye Başkan Yardımcısı } \\
\hline Müdür & Bilgi Işlem Müdürlüğü \\
\hline Müdür & Destek Hizmetleri Müdürlüğü \\
\hline Müdür & Emlak ve İstimlak Müdürlüğü \\
\hline Müdür & Etüt Proje Müdürlüğü \\
\hline Müdür & Fen İşleri Müdürlüğü \\
\hline Müdür & Hukuk İşleri Müdürlüğü \\
\hline Müdür & İmar ve Şehircilik Müdürlüğü \\
\hline Müdür & İnsan Kaynakları Müdürlüğü \\
\hline Müdür & İşletme ve İştirakler Müdürlüğü \\
\hline Müdür & Mali Hizmetler Müdürlüğü \\
\hline Müdür & Kültür ve Sosyal İşler Müdürlüğü \\
\hline Müdür & Özel Kalem Müdürlüğü \\
\hline Müdür & Park ve Bahçeler Müdürlüğü \\
\hline Müdür & Ruhsat ve Denetim Müdürlüğü \\
\hline Müdür & Muhtarlık İşleri Müdürlüğü \\
\hline Müdür & Sağlık İşleri Müdürlüğü \\
\hline Müdür & Temizlik İşleri Müdürlüğü \\
\hline Müdür & Yapı Kontrol Müdürlüğü \\
\hline Müdür & Yazı İşleri Müdürlüğü \\
\hline Müdür & Zabıta Müdürlüğü \\
\hline
\end{tabular}

Kaynak: (Edremit Belediyesi, 2019)

Örneklemi ise burada görevli müdürler oluştururken, Belediye bünyesinde müdür yardımCISı pozisyonu bulunmamaktadır. Ilggili rakamlar göz önüne alındığında örneklemin evreni temsil oranı \%87'dir. Anket araştırması için 2018 Aralık ayında Edremit Belediyesi Özel Kalem Müdürlüğü ile iletişime geçilmiş, anket soruları teslim edilmiş; konuyla ilgilenen belediye başkan yardımcısının izni ve yönlendirmesiyle örnekleme dâhil edilen 20 müdürden 17'si anket sorularını yanıtlamıştır. Araştırma kapsamında 17 müdürden alınan yanıtlar Tablo 8 ve Tablo 9'da derlenmiştir. Araştırma sonuçları SPSS istatistik programının 22. Sürümünde Cronbach's Alpha güvenilirlik analizine tabi tutulmuş, burada çıkan sonuç 0.78 olmuştur. Kaya'nın belirttiğine göre Cronbach's Alpha güvenilirlik değeri için 0.70 ve üzeri güvenilir bir değerdir (Kaya, 2013: 185). 


\subsection{Araştırmanın Bulguları}

Tablolarda verilen önermelerin sonuçları yorumlanırken "katılıyorum" ve "kesinlikle katılıyorum" yanıtlarıyla; "katılmıyorum" ve "kesinlikle katılmıyorum" yanıtları birlikte değerlendirilmiştir.

Tablo 8: Liderlik Konusuyla ilgili Önermeler

\begin{tabular}{|c|c|c|c|c|c|c|c|c|c|c|}
\hline \multirow[t]{2}{*}{ Önermeler } & \multicolumn{2}{|c|}{ 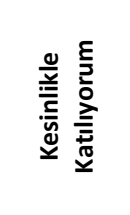 } & \multicolumn{2}{|c|}{ 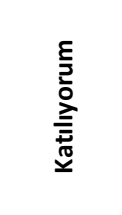 } & \multicolumn{2}{|c|}{ 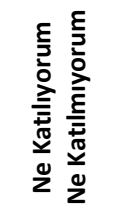 } & \multicolumn{2}{|c|}{ 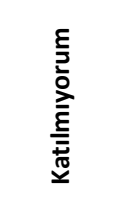 } & \multicolumn{2}{|c|}{ 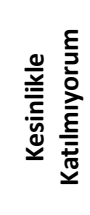 } \\
\hline & $\mathbf{n}$ & $\%$ & $\mathrm{n}$ & $\%$ & $\mathbf{n}$ & $\%$ & $\mathbf{n}$ & $\%$ & n & $\%$ \\
\hline $\begin{array}{l}\text { 1.1. Liderlik yeteneği tüm yöneticilerde bulunması } \\
\text { gereken bir özelliktir. }\end{array}$ & 12 & 70,5 & 4 & 23,5 & 1 & 5,9 & 0 & 0 & 0 & 0 \\
\hline $\begin{array}{l}\text { 1.2. Belediye başkanının liderlik yeteneğine sahip olması } \\
\text { bir gerekliliktir. }\end{array}$ & 15 & 88,3 & 2 & 11,7 & 0 & 0 & 0 & 0 & 0 & 0 \\
\hline $\begin{array}{l}\text { 1.3. Belediye başkan yardımcısının liderlik yeteneğine } \\
\text { sahip olması bir gerekliliktir. }\end{array}$ & 11 & 64,7 & 5 & 29,4 & 1 & 5,9 & 0 & 0 & 0 & 0 \\
\hline $\begin{array}{l}\text { 1.4. Belediye genel sekreterinin ve yardımcılarının liderlik } \\
\text { yeteneğine sahip olması bir gerekliliktir. }\end{array}$ & 10 & 58,8 & 4 & 23,5 & 3 & 17,6 & 0 & 0 & 0 & 0 \\
\hline $\begin{array}{l}\text { 1.5. Belediye daire başkanının liderlik yeteneğine sahip } \\
\text { olması bir gerekliliktir. }\end{array}$ & 11 & 64,7 & 5 & 29,4 & 1 & 5,9 & 0 & 0 & 0 & 0 \\
\hline $\begin{array}{l}\text { 1.6. Belediyede görev yapan müdürün liderlik yeteneği- } \\
\text { ne sahip olması bir gerekliliktir. }\end{array}$ & 9 & 53 & 7 & 41 & 1 & 5,9 & 0 & 0 & 0 & 0 \\
\hline $\begin{array}{l}\text { 1.7. Türkiye genelinde hâlihazırda görevde olan belediye } \\
\text { üst kademe yöneticilerinin, liderlik eğitimi almaları doğru } \\
\text { bir uygulama olur. }\end{array}$ & 9 & 53 & 6 & 35,2 & 2 & 11,7 & 0 & 0 & 0 & 0 \\
\hline $\begin{array}{l}\text { 1.8. Hayatında ilk defa belediye başkanı seçilen bir } \\
\text { kişinin liderlik eğitimi alması faydalı olur. }\end{array}$ & 11 & 64,7 & 4 & 23,5 & 1 & 5,9 & 1 & 5,9 & 0 & 0 \\
\hline $\begin{array}{l}\text { 1.9. Hayatında ilk defa belediye başkan yardımcısı olan } \\
\text { bir kişinin liderlik eğitimi alması faydalı olur. }\end{array}$ & 10 & 58,8 & 5 & 29,4 & 1 & 5,9 & 1 & 5,9 & 0 & 0 \\
\hline $\begin{array}{l}\text { 1.10. Hayatında ilk defa belediyede müdür olan bir } \\
\text { kişinin liderlik eğitimi alması faydalı olur. }\end{array}$ & 10 & 58,8 & 6 & 35,2 & 0 & 0 & 1 & 5,9 & 0 & 0 \\
\hline $\begin{array}{l}\text { 1.11. Hayatında ilk defa belediyede genel sekreter veya } \\
\text { yardımcısı olan bir kişinin liderlik eğitimi alması faydalı } \\
\text { olur. }\end{array}$ & 9 & 53 & 4 & 23,5 & 1 & 5,9 & 3 & 17,6 & 0 & 0 \\
\hline $\begin{array}{l}\text { 1.12. Hayatında ilk defa belediyede daire başkanı olan } \\
\text { bir kişinin liderlik eğitimi alması faydalı olur. }\end{array}$ & 10 & 58,8 & 5 & 29,4 & 1 & 5,9 & 1 & 5,9 & 0 & 0 \\
\hline
\end{tabular}

Liderlik eğitimleriyle ilgili olarak; liderlik yeteneğinin tüm yöneticilerde bulunması gereken bir özellik olduğunu düşünenlerin oranı \%94'tür [Önerme 1.1.]. Bu kapsamda, bir belediye başkanın liderlik yeteneğine sahip olması gerektiğini düşünenlerin oranı \%100'dür [Önerme 1.2.]. Bu rakam, belediye başkanının tamamen bir lider olarak görüldüğünü göstermektedir. Aynı soru daha alt kademe yöneticilere göre yöneltildiğinde; başkan yardımcısının liderlik yeteneğine sahip olması gerektiğini düşünenlerin oranı \%94,1 [Önerme 1.3.]; genel sekreter ve yardımcılarının liderlik yeteneğine sahip olmaları gerektiğini düşünenlerin oranı \%82,3 [Önerme 1.4.]; belediye daire başkanının liderlik yeteneğine sahip olması gerektiğini düşünen- 
lerin oranı \%94,1 [Önerme 1.5.]; müdürün liderlik yeteneğine sahip olması gerektiğini düşünenlerin oranı ise \%94'dür [Önerme 1.6.]. Rakamlar göstermektedir ki; üst kademe yöneticilerin liderlik vasıflarına sahip olmaları bir gerekliliktir. Türkiye genelinde belediyelerde görev yapan üst kademe yöneticilere liderlik eğitimlerinin verilmesi gerektiği önermesine ise; cevap verenlerin \%88,2'si olumlu görüş belirtmiştir [Önerme 1.7.]. Hayatında ilk defa belediye başkanı, başkan yardımcısı, daire başkanı, müdür, genel sekreter ve genel sekreter yardımcısı olacak kişilerin; belirli bir liderlik eğitimi alması gerektiği önermesine de katılımcılar \%76,5 üzerinde olumlu görüş belirtmişlerdir [Önerme 1.8., 1.9., 1.10., 1.11. ve 1.12.]. Tablo 8'deki önermelere bakarak şu sonuca varılabilmektedir; belediye üst kademe yöneticilerine göre, belediye üst kademe yöneticileri liderlik özelliklerine sahip olmalıdırlar ve bu yönde hem görevde olan hem de göreve yeni başlayacak olan kişilere liderlik alanında eğitimlerin verilmesi gerekmektedir.

Tablo 9: Mesleki Eğitimle Ilgili Önermeler

\begin{tabular}{|c|c|c|c|c|c|c|c|c|c|c|}
\hline \multirow[t]{2}{*}{ Önermeler } & \multicolumn{2}{|c|}{ 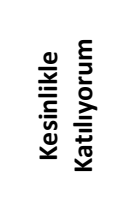 } & \multicolumn{2}{|c|}{ 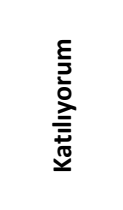 } & \multicolumn{2}{|c|}{ 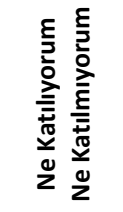 } & \multicolumn{2}{|c|}{ 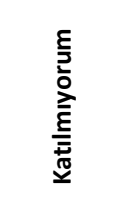 } & \multicolumn{2}{|c|}{ 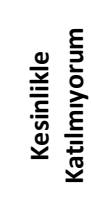 } \\
\hline & $\mathrm{n}$ & $\%$ & 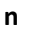 & $\%$ & $\mathbf{n}$ & $\%$ & $n$ & $\%$ & $\mathbf{n}$ & $\%$ \\
\hline $\begin{array}{l}\text { 2.1. Mesleki eğitim göreve yeni başlayan tüm kamu } \\
\text { çalışanlarına verilmelidir. }\end{array}$ & 12 & 70,5 & 4 & 23,5 & 1 & 5,9 & 0 & 0 & 0 & 0 \\
\hline $\begin{array}{l}\text { 2.2. Mevcut durumda, Türkiye genelindeki belediye üst } \\
\text { kademe yöneticilerinin temel mesleki bilgileri yeterlidir. }\end{array}$ & 0 & 0 & 2 & 11,7 & 5 & 29,4 & 10 & 58,8 & 0 & 0 \\
\hline
\end{tabular}

2.3. Türkiye genelindeki mevcut belediye üst kademe yöneticilerinin, güncel ve yenilikçi kent yönetimi yaklaşımlarıyla ilgili olarak bir mesleki eğitim almaları faydalı olur.

2.4. Hayatında ilk defa belediye başkanı seçilen bir

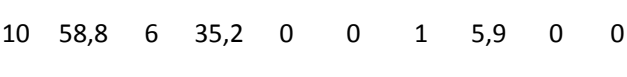
kişinin, göreve başlamadan önce temel bir mesleki eğitim alması faydalı olur.

2.5. Hayatında ilk defa belediye başkan yardımcısı olan bir kişinin, göreve başlamadan önce temel bir mesleki eğitim alması faydalı olur.

2.6. Hayatında ilk defa belediyede müdür olan bir kişinin, göreve başlamadan önce temel bir mesleki eğitim alması faydalı olur.

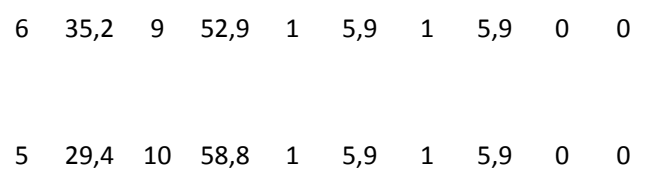

2.7. Hayatında ilk defa belediyede genel sekreter veya genel sekreter yardımcısı olan bir kişinin, göreve başlamadan önce temel bir mesleki eğitim alması faydalı olur.

2.8. Hayatında ilk defa belediyede daire başkanı olan bir kişinin, göreve başlamadan önce temel bir mesleki eğitim alması faydalı olur.

2.9. Bana verilecek bir liderlik eğitimi benim için faydalı olur.

$\begin{array}{llllllllll}8 & 47 & 8 & 47 & 1 & 5,9 & 0 & 0 & 0 & 0\end{array}$

$\begin{array}{llllllllll}9 & 52,9 & 7 & 41,1 & 1 & 5,9 & 0 & 0 & 0 & 0\end{array}$

$\begin{array}{llllllllll}5 & 29,4 & 8 & 47 & 1 & 5,9 & 3 & 17,6 & 0 & 0\end{array}$ 
2.10. Bana verilecek yenilikçi ve güncel bir mesleki eğitim benim için faydalı olur.

2.11. Belediye üst kademe yöneticilerinin mesleki bilgi birikimleri, ilgili kente verilecek hizmetlerin kalitesini etkilemektedir.

\author{
$\begin{array}{llllllllll}13 & 76,4 & 4 & 23,5 & 0 & 0 & 0 & 0 & 0 & 0\end{array}$ \\ $\begin{array}{llllllllll}9 & 52,9 & 4 & 23,5 & 2 & 11,7 & 2 & 11,7 & 0 & 0\end{array}$
}

2.12. Liderlik ve mesleki bilgi eğitimlerinin, kendi belediyemiz yerine merkezi yönetim tarafından verilmesi daha etkin ve verimli olur.

Mesleki eğitimlerle ilgili olarak; mesleki eğitimin tüm kamu çalışanları için bir gereklilik olduğunu düşünenlerin oranı \% 94'tür [Önerme 2.1.]. Bu konuyla ilgili olarak, Türkiye genelinde mevcut belediye üst kademe yöneticilerinin yeterli seviyede mesleki bilgiye sahip olduğunu düşünenlerin oranı sadece \%11,7'dir [Önerme 2.2.]. Bu eksikliğin giderilmesi için, mevcut belediye üst kademe yöneticilerine güncel ve yenilikçi kent yönetim eğitimlerinin verilmesi gerektiğini düşünenlerin oranı ise \% 94'tür [Önerme 2.3.]. Hayatında ilk defa belediyede başkan, başkan yardımcısı, daire başkanı, müdür, genel sekreter ve genel sekreter yardımcısı olan bir kişinin; göreve başlamadan önce temel bir mesleki eğitim alması gerektiği önermesine yüksek seviyede olumlu görüş belirtilmiş ve oranlar \% $88^{\prime}$ in üzerinde çıkmıştır [Önerme 2.4., 2.5., 2.6., 2.7. ve 2.8.]. Çalışmaya katılanların $\% 76,4^{\prime}$ ü kendilerine verilecek bir liderlik eğitiminin faydalı olacağını belirtirken [Önerme 2.9.]; bu oran mesleki eğitimlerle ilgili olarak \% 94'e çıkmaktadır [Önerme 2.10.]. Belediye üst kademe yöneticilerinin mesleki yönden birikimli olmalarının kente yarar sağlayacağını düşünenlerin oranı \%100'dür [Önerme 2.11.]. Tüm bunlara ek olarak, liderlik ve mesleki eğitimlerin belediye üst kademe yöneticilerine merkezi yönetim tarafından verilmesinin doğru olacağını düşünenlerin oranı \% 76,4'tür [Önerme 2.12.]. Yerel yönetimde gerçekleştirilen bir anket çalışmasına, merkezi yönetimi ön plana çıkartacak bir cevap verilmesi; bu eğitimlerin daha profesyonelce verilmesine duyulan ihtiyacı göstermektedir. Tablo 9'daki önermelere bakarak şu sonuca varılabilmektedir; belediye üst kademe yöneticileri mesleki yönden eğitime ihtiyaç duymaktadırlar ve bu yönde isteklidirler.

\title{
6. Sonuç ve Eğitim Modeli Önerisi
}

Belediyede görevli başkan, başkan yardımcısı, daire başkanı, müdür, genel sekreter ve genel sekreter yardımcısı pozisyonlarından oluşan belediye üst kademe yöneticilerinin sahip oldukları liderlik kapasitelerinin arttırılması; belediyenin kendi iç yapısındaki personelin daha etkin bir şekilde sevk ve idare edilmesine katkı sağlayabilecektir. Yine bu üst kademe yöneticilerinin sahip oldukları mesleki bilgi kapasitelerinin geliştirilmesi de kentin daha iyi yönetilmesine ve geliştirilmesine katkı sağlayabilecektir. Bu sebeple hem liderlik hem de mesleki eğitimlerin birlikte; göreve ilk defa başlayan belediye üst kademe yöneticilerine verilmesi uygun olabilir. Fakat bu eğitimlerin göreve ilk atanan kişilere, henüz görevi devralmadan önce verilmesi düşünülmelidir. Burada amaç, göreve yeni başlayacak olan idareciyi olabildiğince hazır bir şekilde çalışmalarına başlatmaktır. Belediyeler siyasi kurumlar olduklarından ve başkanları seçim yoluyla göreve geldiklerinden dolayı; daha öncesinden hayatında hiç yöneticilik yapmamış veya kurumsal bir idarede çalışmamış kişiler bu görevlere gelebilmektedirler. Bu durum demokrasi açısından son derece normaldir. Örneğin daha öncesine kadar avukat, doktor, mühendis, esnaf, memur veya diğer mesleklerde görev yapan bir kişi, bir anda kentin en yetkili makamına seçilebilmektedir. Fakat burada önemli olan konu, demokrasinin gereği olarak göreve gelen kişileri olabildiğince göreve hazırlamaktır. 
Türkiye ölçeğinde yerel yönetimlerle ilgili kanun ve yönetmeliklere bakıldığında, belediye üst kademe yöneticilerine yönelik bir standart eğitim programının bulunmadığı görülmektedir. Belediye birlikleri gibi kurumların gönüllü katılım şeklinde bu eğitimleri alt kademe belediye personeline verdikleri görülmektedir. Dolayısıyla belediye üst kademe yöneticilerine yönelik standarda bağlanmış ve zorunlu tutulan eğitimlere ihtiyaç duyulduğu söylenebilir. Bu çalışma içerisinde yer alan araştırma da bu sonucu ortaya koymaktadır. Ilgili araştırmaya katılan belediye üst kademe yöneticileri kendilerine verilecek liderlik ve meslek içi eğitimlere ihtiyaç duyduklarını belirtmektedirler.

Bu kapsamda ortaya konulacak eğitimleri Çevre ve Şehircilik Bakanlığı bünyesinde bulunan Yerel Yönetimler Genel Müdürlüğü organize edebilir. Böylece merkezi yönetimin geniş uzman gücüne dayanan ve tüm yöneticilere eşit kalitede eğitimin verilmesini mümkün kılan programlar hayata geçirilebilir. Eğitim programının süresi üç ay olarak belirlenebilir. Bu üç aylık zaman dilimi de farklı eğitim konularını içeren ve her biri, birer aydan oluşan üç programa ayrılabilir. Bu eğitimlerin daha profesyonelce, disiplinli ve etkin bir şekilde verilebilmesi için kurum dışı eğitim modeli kullanılabilir.

Konuyla ilgili olarak bu çalışmada bir eğitim programı önerisi hazırlanmıştır. Bu eğitim programı ile amaçlanan Türkiye'de kentlerin en önemli hizmet yüklenicisi olan belediyelerin daha etkin ve verimli hizmet üretmelerine katkı sağlamaktır. Böylece belediye üst kademe yöneticileri için standart ve katılımın zorunlu tutulduğu bir eğitim programının ortaya konulması hedeflenmiştir. Eğitim programı hazırlanırken hem bu çalışma içerisinde başvurulan kaynaklardan yararlanılmıştır, hem de aşağıdaki kaynaklardan yararlanılmıştır;

- Bilgin, Ufuk Kamil; Akay, Aslı; Koyuncu, Emre ve Haşar, Çetin. (2007), Yerel Yönetimlerde Hizmet İçi Eğitim, Ankara: Tepav Yayınları.

- Hannum, Kelly; Martineau, Jennifer ve Reinelt, Claire. (2007), The Handbook of Leadership Development Evaluation, San Francisco: John Wiley and Sons.

- Eğitim Kataloğu, Marmara Belediyeler Birliği, http://marmara.gov.tr/UserFiles/Attachments/2018/06/22/7e3f2289-ede3-4452-9905adf9a951f4e1.pdf, (Erişim Tarihi: 24.2.2019).

- Yaman, Ertuğrul. (2014), Yerel Yönetimlerde Lider Yöneticilik, Ankara: Türkiye Belediyeler Birliği Yayınları.

- Belediye Akademisi, Türkiye Belediyeler Birliği, http://www.tbb.gov.tr/belediyeakademisi/egitimler/gecmis-egitimler/page-1/, (Erişim Tarihi: 24.2.2019).

- Kirchner, Michael ve Akdere, Mesut (2014), "Leadership Development Programs: an Integrated Review of Literature", Bilgi Ekonomisi ve Yönetimi Dergisi, C. 9, S. 1: 137-146.

- Bahçeşehir Üniversitesi Yerel Yönetimler Akademisi, https://bau.edu.tr/icerik/13579yerel-yonetimler-akademisi-9-sertifika-programi-basvurulari-basladi, (Erişim Tarihi: 23.2.2019).

- Yerel Yönetim Araştırma Yardım ve Eğitim Derneği, http://www.yayed.org/yayed6/egitim-verilen-konular.php, (Erişim Tarihi: 23.2.2019).

- Mahalli İdareler Derneği, http://www.mahalliidarelerdernegi.org.tr/etkinlik_64_yerelyonetimler-egitim-programi, (Erişim Tarihi: 23.2.2019). 
A- Temel Mesleki Eğitime Yönelik Birinci Ay Eğitimleri: Bu kapsamda verilecek olan eğitimler yurt içinde Ankara'da, Yerel Yönetimler Genel Müdürlüğü bünyesinde verilebilir. Belirli sayıdaki üst kademe yöneticileri gruplar halinde bu eğitim programlarına katılarak temel mesleki eğitimlerini alabilirler. Böylece seçilmiş veya atanmış kişiler görevlerinin sorumluluklarını daha iyi idrak edebilir ve temel uzmanlık bilgilerini pekiştirebilirler. Bu kapsamda verilecek olan eğitimlerin içeriği şu şekilde olabilir;

- Temel yasal mevzuat (Belediye Kanunu, Büyükşehir Belediye Kanunu, Belediye Gelirleri Kanunu, İmar Kanunu, Mahalli İdareler Personelinin Görevde Yükselme ve Unvan Değişikliği Esaslarına Dair Yönetmelik, Mahalli İdare Birlikleri Kanunu, Köy Kanunu, İ Özel İdaresi Kanunu, Yatırım İzleme ve Koordinasyon Başkanlığı Yönetmeliği, Kent Estetik Kurulu ÇaIışma Usul ve Esaslarına İliş̧in Yönetmelik, İ Özel İdarelerine ve Belediyelere Genel Bütçe Vergi Gelirlerinden Pay Verilmesi Hakkında Kanun, Belediye ve Bağlı Kuruluşları ile Mahalli İdare Birlikleri Norm Kadro İlke ve Standartlarına Dair Yönetmelik, Kent Konseyi Yönetmeliği)

- Çevre mevzuat (Avrupa Yerel Yönetimler Özerklik Şartı, Avrupa Kentsel Şartı, Aarhus Sözleşmesi, Aalborg Sözleşmesi, Birleşmiş Milletler İklim Değişikliği Çerçeve Sözleşmesi, Yerel Gündem 21)

- Sosyal belediyecilik;

- Kentsel markalaşma;

- Yerel turizm;

- Kent kültürü;

- Yönetişim - katılımcılık;

- Yerel ekonomi ve yerel kalkınma;

- Mali yönetim;

- Risk yönetimi;

- İç denetim;

- Toplam kalite yönetimi;

- Stratejik planlama ve yönetim;

- E-belediyecilik uygulamaları;

- Performans yönetimi ve denetimi;

- Belediyelerde yap - işlet - devret modeli;

- Belediyelerde tahvil ihracı;

- Kurum içi katılımcılık ve iletişim;

- Küreselleşme;

- Müdürlere yönelik olarak kendi alanlarıyla ilgili diğer teknik eğitimler.

B- Temel Mesleki Eğitime Yönelik ikinci Ay Eğitimleri: Göreve yeni seçilen veya atanan belediye üst kademe yöneticileri yerinde gözlem yapmak, uygulamaları doğrudan tecrübe etmek ve yeni bir vizyon kazanmak için Avrupa ülkelerini içeren bir yurtdışı eğitim programına alınabilirler. Burada Avrupa ülkelerinin seçilme sebebi, bu ülkelerde bulunan şehirlerin uluslararası yaşam kalitesi araştırmalarında üst seviyelerde yer almalarındandır (Mercer, 2018). Eğitim programı kapsamında aşağıda belirtilen alanlarda öne çıkan Avrupa kentleri bizzat ziyaret edilerek, çalışmalar yerinde gözlemlenebilir. Yurtdışında yerinde incelenecek ve tecrübe edilecek olan eğitimin içeriği ise şu şekilde olabilir;

- Ulaşım sistemleri; 
- Atık geri dönüşüm sistemleri;

- Kentsel dönüşüm;

- Kent estetiği;

- Yönetişim ve katılımcılık;

- Engellilere uygun kentleşme;

- Yenilenebilir enerji kaynakları;

- Teknolojik kent uygulamaları;

- Ekolojik kentleşme;

- Kent kimliği;

- Akıllı şehir uygulamaları;

- Altyapı sistemleri;

- Kentsel yaşam kalitesi;

- Kent planlama;

- Gençlere, kadınlara ve yaşlılara yönelik kentleşme.

C- Liderlik Kavramına Yönelik Üçüncü Ay Eğitimleri: Bu kısımda belediye üst kademe yöneticilerine verilecek eğitimler, yöneticilere kendi şehirlerinin üniversiteleri üzerinden verilebilir. Günümüzde hemen her şehirde bir üniversite mevcuttur. Bu kısımda daha çok liderlik ve yöneticilikle ilgili teknik bilgiler aktarılabilir. Bu kapsamda şöyle bir eğitim programı uygun olabilir;

- Liderin sahip olması gereken temel nitelikler;

- Liderlik davranışları (demokratik, otokratik, serbestiyetçi);

- Liderlikte modern yaklaşımlar (karizmatik, hizmetkâr, işlemci, dönüştürücü, stratejik);

- Liderliğin güç kaynakları (yasal, karizmatik, zorlayıcı, ödüllendirme, uzmanlık);

- $\quad$ Lider ve yöneticinin özellikleri ve farkları;

- Vizyon ve misyon belirleme;

- Hedef belirleme;

- Ekip oluşturma;

- İş takip sistemi kurma;

- Etkili iletişim ve hitabet;

- Beden dili;

- Zaman yönetimi;

- Kriz yönetimi;

- Insan kaynakları yönetimi;

- Etik değerler.

Bu üç kısımlı eğitim programıyla, belediye üst kademe yöneticilerinin Yerel Yönetimler Genel Müdürlüğü bünyesinde en geniş ölçekte eğitime alınmaları sağlanabilir. Üç aylık bir zaman diliminde verilecek eğitimlerle; kent idarecilerinin hem temel görev bilincine ulaşmaları hem de vizyoner birer yönetici haline getirilmeleri mümkün olabilir. Yurtiçinde verilecek temel mesleki eğitimler, yurtdışında yerinde yapılacak gözlemler ve liderlik vasfını geliştirmeye yönelik eğitimler; mevcut durumda hiç eğitim verilmemesine göre çok daha yerinde bir çalışma olabilir. Günümüzde belediyelerin sahip oldukları büyük bütçeler bu eğitimlerin verilmesi için oldukça geniş imkânları sunmaktadır. Ayrıca günümüzde artan üniversite sayıları ve güçlü merkezi yönetim bürokrasisi; geniş bir uzman eğitimci kadrosunu da göreve hazır kılmaktadır. 
Dolayısıyla bu eğitim programı için gerekli olan beşeri ve maddi kaynak hali hazırda mevcuttur.

Kentler doğru kurgulandıkları ve idare edildikleri takdirde içinde yaşayanların mutlu oldukları ve insanların kendilerini geliştirebildikleri mekânlara dönüşebilirler. Ayrıca doğru bir şekilde idare edilen kentler makro (ülkesel) gelişime de katkı sunan bir konuma gelebilirler. Bu kapsamda makro gelişim için mikro (kentsel) gelişimin önemli bir basamak olduğu göz önünde bulundurulmalı ve Türkiye'de kentlerin daha etkin bir şekilde idare edilmeleri için, belediye üst kademe yöneticilerinin vasıfları olabildiğince geliştirilmelidir. 


\section{Kaynaklar}

5393 sayılı Belediye Kanunu, 2005, MD. 14.

Arıkan, Ersin; Kılıç, Gonca ve Becerikli, Gizem (2017), "Karizmatik Liderlik Ve Örgütsel Vatandaşlık Davranışı Arasındaki İlişki: Kuşadası'ndaki Beş Yıldızıı Otel İşletmelerinde Bir Uygulama”, Türk Turizm Araştırmaları Dergisi, C. 1, S. 4: 119.

Bahçeşehir Üniversitesi Yerel Yönetimler Akademisi, https://bau.edu.tr/icerik/13579-yerel-yonetimler-akademisi-9sertifika-programi-basvurulari-basladi, (Erişim Tarihi: 23.2.2019).

Bakan, İsmail ve Büyükbeşe, Tuba (2010), “Liderlik Türleri Ve Güç Kaynaklarına İlişkin Mevcut Gelecek Durum Karşılaştırması: Eğitim Kurumu Yöneticilerinin Algılarına Dayalı Bir Alan Araştırması", KMÜ Sosyal ve Ekonomik Araştırmalar Dergisi, C. 12, S. 19: 73-84.

Balay, Refik; Kaya, Ahmet ve Yılmaz, Reyhan Geçdoğan (2014), "Eğitim Yöneticilerinin Hizmetkar Liderlik Yetenekleri ile Farklılıkları Yönetme Becerileri Arasındaki İlişki”, Eğitim Bilimleri Araştırmaları Dergisi, C. 4, S. 1: 229-249.

Bass, Bernard M. ve Riggo, Ronald E. (2005), Transformational Leadership, 2. Basım, Londra: Lawrance Erlbaum Associates Yayınları.

Belediye Akademisi, Türkiye Belediyeler Birliği, http://www.tbb.gov.tr/belediye-akademisi/egitimler/gecmisegitimler/page-1/, (Erişim Tarihi: 24.2.2019).

Bertocci, David I. (2009), Leadership In Organizations, Maryland: University Press Of America Yayınları.

Bilgin, Ufuk Kamil; Akay, Aslı; Koyuncu, Emre ve Haşar, Çetin. (2007), Yerel Yönetimlerde Hizmet Içi Eğitim, Ankara: Tepav Yayınları.

Bozlağan, Recep (2005), Liderlik Yaklaşımları ve Belediyeler, İstanbul: Hayat Yayınları.

Cavazotte, Flávia; Moreno, Valter ve Bernardo, Jane (2013), "Transformational Leaders and Work Performance: The Mediating Roles of Identification and Self-efficacy", Brazilian Administration Review, C. 10, S. 4: 490-512.

Conger, Jay ve Kanungo, Rabindra(1998), Charismatic Leadership in Organisations, Londra: Sage Yayınevi.

Davies, Barbara J. ve Davies, Brent (2004), "Strategic leadership", School Leadership \& Management, C. 24, S. 1: 2938.

Demirtaş, Zülfü (2010), “Öğretmeni Hizmet İçinde Yetiştirmenin Bir Aracı Olarak Denetim”, Elektronik Sosyal Bilimler Dergisi, C. 9, S. 31: 41-52.

Devlet Memurları Kanunu, 1965, MD. 214, 215, 216, 218.

Edremit Belediyesi, http://www.edremit.bel.tr/category/kurumsal/mudurluklerimiz/, (Erişim Tarihi: 24.2.2019).

Eğitim Kataloğu, Marmara Belediyeler Birliği, http://marmara.gov.tr/UserFiles/Attachments/2018/06/22/7e3f2289ede3-4452-9905-adf9a951f4e1.pdf, (Erişim Tarihi: 24.2.2019).

E-içişleri, https://www.e-icisleri.gov.tr/Anasayfa/MulkildariBolumleri.aspx, (Erişim: 2.12.2018)

Flynn, Francis ve Staw, Barry (2004), "Lend Me Your Wallets: The Effect Of Charismatic Leadership On External Support For An Organization”, Strategic Management Journal, C. 25, S. 4: 309-330.

Görmüş, Alparslan Şahin ve Kâhya, Vasfi (2014), “Hizmet İçi Eğitim Programlarının Kamu Çalışanlarının Motivasyonuna Etkisi: Eti Maden İşletmelerinde Bir Uygulama”, Optimum Ekonomi ve Yönetim Bilimleri Dergisi, C. 1, S. 1: 37-49.

Hannum, Kelly; Martineau, Jennifer ve Reinelt, Claire. (2007), The Handbook of Leadership Development Evaluation, San Francisco: John Wiley and Sons.

Ingram, Osmond C. (2016), "Servant Leadership as A Leadership Model", JMSBI, C. 1, S. 1: 21-26.

ỉbicioğlu, Hasan; Özmen, İbrahim ve Taş, Sebahattin (2009), “Liderlik Davranışı ve Toplumsal Norm İlişkisi: Ampirik Bir Çalışma”, Süleyman Demirel Üniversitesi Iktisadi ve Idari Bilimler Fakültesi Dergisi, C. 14, S. 2: 1-23.

Judge, Timothy A. ve Piccolo, Ronald F. (2004), "Transformational and Transactional Leadership: A Meta-Analytic Test of Their Relative Validity", Journal of Applied Psychology, C. 89, S. 5: 755-768.

Karasar, Niyazi (2012), Bilimsel Araştırma Yöntemi, Ankara: Nobel Yayınevi.

Kaya, Mehmet Fatih (2013), "Sürdürülebilir Kalkınmaya Yönelik Tutum Ölçeği Geliştirme Çalışması”, Marmara Coğrafya Dergisi, S.28: 175-193.

Kaygın, Erdoğan ve Kaygın, Ceyda Yerdelen (2012), “Çalışanların Dönüştürücü Liderlik Algılarını Belirlemeye Yönelik Bir Araştırma”, Organizasyon ve Yönetim Bilimleri Dergisi, C. 4, S. 2: 29-38. 


\section{Eskişehir Osmangazi Üniversitesi IïB Dergisi}

Kılıç, Recep; Keklik, Belma ve Yıldır, Harun (2014), “Dönüştürücü, Etkileşimci ve Tam Serbesti Tanıyan Liderlik Tarzlarının Örgütsel Sessizlik Üzerindeki Etkisini Belirlemeye Yönelik Bir Araştırma”, Yönetim ve Ekonomi, C. 21, S. 2: 249268.

Kirchner, Michael ve Akdere, Mesut (2014), "Leadership Development Programs: an Integrated Review of Literature", Bilgi Ekonomisi ve Yönetimi Dergisi, C. 9, S. 1: 137-146.

Korkmaz, Yasin (2017), Liderlik Türlerinin Örgütsel Bağlıığa Etkisi: Kamu Çalışanları Üzerinde Bir Alan Araştırması, Nişantaşı Üniversitesi, İşletme Yönetimi Bilim Dalı, Yüksek Lisans Tezi.

Luthans, Fred (2011), Organizational Behaviour, 12. Basım, New York: McGraw-Hill Yayınevi.

Mahalli İdareler Derneği, http://www.mahalliidarelerdernegi.org.tr/etkinlik_64_yerel-yonetimler-egitim-programi, (Erişim Tarihi: 23.2.2019).

McCleskey, Jim Allen (2014), "Situational, Transformational, and Transactional Leadership and Leadership Development", Journal of Business Studies Quarterly, C. 5, S. 4: 117-130.

Mercer, https://mobilityexchange.mercer.com/Insights/quality-of-living-rankings, (Erişim: 18.12.2018)

Nikoloski, Krume (2015), “Charismatic Leadership And Power: Using The Power Of Charisma For Better Leadership In The Enterprises", Journal of Process Management, C. 3, S. 2: 18-27.

Odumeru, James ve Ogbonna, Ifeanyi George (2013), "Transformational vs. Transactional Leadership Theories: Evidence in Literature", International Review of Management and Business Research, C. 2, S. 2: 355-361.

Oplinger, James; Lande, Micah; Jordan, Shawn ve Camarena, Leonor (2016), “Making Leaders: Leadership Characteristics Of Makers And Engineers in The Maker Community", American Journal of Engineering Education, C. 7, S. 2: 65-82.

Önen, Mustafa ve Kanayran, Hasibe Gül (2015), "Liderlik ve Motivasyon: Kuramsal Bir Değerlendirme", Birey ve Toplum, C. 5, S. 10: 43-63.

Özkan, Metin (2016), “Liderlik Hangi Sıfatları, Nasıl Alıyor? Liderlik Konulu Makalelerin İncelenmesi”, Gaziantep University Journal of Social Sciences, C. 16, S. 2: 615-639.

Özsalmanlı, Ayşe Yıldız (2005), "Türkiye'de Kamu Yönetiminde Liderlik ve Lider Yöneticilik”, Manas Üniversitesi Sosyal Bilimler Enstitüsü Dergisi, C. 7, S.13: 137-146.

Öztürk, Mustafa ve Sancak, Süleyman (2012), "Hizmet İçi Eğitim Uygulamalarının Çalışma Hayatına Etkileri”, Journal Of Yasar University, C. 2, S. 7: 761-794.

Peker, Kadir (2010), “Kamu Kurum ve Kuruluşlarında Hizmet İçi Eğitim Ve Yöntemleri”, Mevzuat Dergisi, S. 156: 1-30.

Quong, Terry ve Walker, Allan (2010), "Seven Principles of Strategic Leadership”, ISEA, C. 38, S. 1: 22-34.

Russel, Robert F. ve Stone, Gregory (2002), "A Review Of Servant Leadership Attributes: Developing A Practical Model", Leaderhip and Organization Development Journal, C. 23, S. 3: 145-157.

Sparks, George (2014), “Charismatic Leadership: Findings Of An Axploratory Investigation Of The Techniques Of Influence", Journal Of Behavioral Studies In Business, C. 7: 1-11.

Spears, Larry (2010), “Character and Servant Leadership: Ten Characteristics of Effective, Caring Leaders”, The Journal of Virtues and Leadership, C. 1, S. 1: 25-30.

Stogdill, Ralph M. (1974), Handbook of Leadership: A Survey of Theory and Research, New York: Free Press Yayınları.

Türkiye Cumhuriyeti Anayasası, 1982, MD. 123, 126, 127.

Uğurluoğlu, Özgür ve Çelik, Yusuf (2009), “Örgütlerde Stratejik Liderlik ve Özellikleri”, Hacettepe Sağlık Idaresi Dergisi, C. 12, S. 2: 121-156.

Vesso, Signe ve Alas, Ruth (2016), “Characteristics of a Coaching Culture in Leadership Style: the Leader's Impact on Culture", Problems and Perspectives in Management, C. 14, S. 2: 306-317.

Yaman, Ertuğrul. (2014), Yerel Yönetimlerde Lider Yöneticilik, Ankara: Türkiye Belediyeler Birliği Yayınları.

Yerel Yönetim Araştırma Yardım ve Eğitim Derneği, http://www.yayed.org/yayed-6/egitim-verilen-konular.php, (Erişim Tarihi: 23.2.2019).

Yukl, Gary (2010), Leadership in Organizations, 7. Basım, New York: Pearson Yayıncılık.

Zaccaro, Stephan; Rittman, Andrea ve Marks, Michelle (2001), "Team Leadership", The Leadership Quarterly, S. 12: 451-483. 